\title{
MOLD POISONING: AN UNRECOGNIZED ENGLISH HEALTH PROBLEM, 1550-1800
}

by

\section{MARY KILBOURNE MATOSSIAN*}

ONE OF the major mysteries of demographic history is the modern rise in population, beginning around the mid-eighteenth century. It occurred in a number of areas in the temperate northern hemisphere, and is best documented in England. Scholars are generally agreed that the increase took place on account of a decline in mortality, particularly child mortality. ${ }^{1}$ But they have not explained this decline, even in the case of England.

A reconstruction of English population trends $1540-1840$, is in progress, and some preliminary results show slow population growth, or stagnation $1650-1740 .^{2}$ Child mortality accounted for the high overall rates. In his study of population in Worcestershire, Eversley ${ }^{3}$ found that the rate of child burials (expressed as a percentage of baptisms) between 1700 and 1799 was as follows:

\section{Quarter}

$1700-1725$

1726-1749

$1750-1774$

1775-1799
Percentage

26.5

35.7

24.7

24.7

\footnotetext{
* Mary Kilbourne Matossian, M.A., Ph.D., Department of History, University of Maryland, College Park, Md. 20742, U.S.A.

' See especially Ronald D. Lee, 'Population in pre-industrial England: an econometric analysis', Quart.J. Econ., 1973, 87: 581-607; and Thomas McKeown, The modern rise of population, London, Edward Arnold, 1976. For other countries see H. Gille, 'The demographic history of the northern European countries in the eighteenth century', Population Studies, 1949, 3, pt. 1: 3-65; and V. M. Kabuzan, Izmeneniia $v$ razmeshchenii naselenii Rossii v XVIII-pervoi polovine XIX v., Moscow, 1971, pp. 52-53.

${ }^{2}$ E. A. Wrigley, 'Mortality in pre-industrial England: the example of Colyton, Devon, over three centuries', in D. V. Glass and R. Revelle (editors), Population and social change, London, Edward Arnold, 1972, pp. 244-273; J. D. Chambers, 'The Vale of Trent, 1670-1800: a regional study of economic change', in D. V. Glass and D. E. C. Eversley (editors), Population in history. Essays in historical demography, London, Edward Arnold, 1965, pp. 327-334; Sölvi Sogner, 'Aspects of the demographic situation in seventeen parishes in Shropshire, 1711-1760', Population Studies, 1963, 17: 126-146; David Levine, Family formation in an age of nascent capitalism, London and New York, Academic Press, 1977, pp. 89, 117.

${ }^{3}$ D. E. C. Eversley, 'A survey of the population in an area of Worcestershire from 1660 to 1850 on the basis of parish registers', Population Studies, 1957, 10: 253-279.
} 


\section{Mary Kilbourne Matossian}

In his study of mortality in Colyton, Wrigley found a sharp drop in the mortality of infants (less than one year old) and of children under five years during the second half of the eighteenth century. ${ }^{4}$ Children of peers, the most privileged in the kingdom, had a relatively short life expectancy at birth in the first half of the eighteenth century, but greatly improved prospects in the second half: ${ }^{5}$

Birth cohort

$1700-1724$

$1725-1749$

1750-1774

1775-1799
Life Expectancy, in years

Male

34.4

38.6

44.5

46.8
Female

36.3

36.7

45.7

49.0

In 1767 Thomas Short, M.D., stated that child mortality had declined in London, since only about 500 out of 1,000 live-born infants died before the age of twenty whereas a century previous 600 out of 1,000 had died before the age of sixteen. ${ }^{6}$

Several possible solutions to the problems of mortality decline after 1740 may be eliminated. Most of the high death rate, 1710-1740, was not the result of starvation. Taking the period $1700-1740$ as a whole, the weather was milder, and food prices lower, than for the preceding sixty-year period.' Salaman concluded that in England "It will be seen that during the first half of the eighteenth century the food of the people was mixed, nutritious, and in general adequate."8

The decline in mortality in the second half of the century probably was not the result of improved medical care or sanitation. The research of McKeown and Brown has suggested that eighteenth-century hospitals had at best a negligible effect on the mortality rate; that medical dispensaries lacked drugs effective against infectious diseases; and that improved sanitation affected only a negligible minority in a few towns.' While E. M. Sigsworth and John Woodward have collected evidence that conditions in eighteenth-century hospitals were not as bad as McKeown and Brown concluded, they have not demonstrated that these conditions took a sharp turn for the

\footnotetext{
4 Wrigley, op. cit., note 2 above, pp. 254-255.

' T. H. Hollingsworth, 'The demography of the British peerage', Population Studies, 1964, supplement $18(2), 56-57$.

- Thomas Short, A comparative history of the increase and decrease of mankind in England and several countries abroad, London, 1767, p. 19.

'J. D. Chambers, Population, economy and society in pre-industrial England, London, Oxford University Press, 1972, p. 96; Gordon Manley, 'Central England temperatures: monthly mean, 1659-1973', Quart. J. R. Meteorol. Soc., 1974, 100: 389-405.

Redcliffe N. Salaman, The history and-social influence of the potato, Cambridge University Press, 1949 , p. 465.

'McKeown, op. cit., note 1 above, pp. 91-109; T. McKeown and R. G. Brown, 'Medical evidence related to English population changes in the eighteenth century', in Glass and Eversley (editors), op. cit., note 2 above, pp. 285-307.
} 
better in the second half of the century. ${ }^{10}$

The decline in mortality probably should not be attributed to declining mortality from any identified infectious disease. The last major visitation of the Black Death in England occurred in 1665-1667; its cessation thereafter made hardly any difference in the annual mortality rate in London. Smallpox, an easily identifiable disease, raged in London without effective check throughout the eighteenth century. The introduction of inoculation in some rural areas may have reduced mortality there, however. ${ }^{11}$

Other diseases which contributed significantly to mortality were called "fevers". In London, during the second half of the eighteenth century, total deaths fell by 16.2 per cent as compared with the first half of the century. The decline in the rate of deaths is unknown, since total population is unknown; but if the population increased, then the decline in the death rate was even greater than 16.2 per cent. Moreover, during the second half of the eighteenth century deaths from "fevers" declined by 28.1 per cent as compared with the first half of the century. Decline in the death rate from "fevers" was even greater if the population increased (Table 1). ${ }^{12}$

TABLE 1 MORTALITY IN LONDON, 1701-1800

\begin{tabular}{lcccr}
\hline Decade & Fever deaths & Total deaths & $\begin{array}{c}\text { \% Fever to } \\
\text { total deaths }\end{array}$ & $\begin{array}{c}\text { \% Change in } \\
\text { total deaths } \\
\text { over previous } \\
\text { decade }\end{array}$ \\
\hline $1701-10$ & 31,163 & 214,611 & 14.5 & -10.9 \\
$1711-20$ & 35,056 & 238,096 & 14.7 & +15.5 \\
$1721-30$ & 39,635 & 274,922 & 14.4 & -3.6 \\
$1731-40$ & 34,823 & 264,925 & 13.1 & -19.2 \\
$1741-50$ & 43,512 & 253,217 & 17.2 & +14.6 \\
$1751-60$ & 26,651 & 204,597 & 13.0 & -8.4 \\
$1761-70$ & 35,237 & 234,412 & 15.0 & +2.1 \\
$1771-80$ & 25,891 & 214,605 & 12.1 & \\
$1781-90$ & 24,599 & 192,700 & 12.8 & \\
$1791-1800$ & 19,880 & 196,801 & 10.1 & -16.2 \\
\hline TOTAL & & & & \\
$1701-50$ & 184,189 & $1,245,770$ & & $\%$ Change over previous 50 years \\
TOTAL & & & -28.1 & -10.1 \\
$1751-1800$ & 132,258 & $1,043,115$ & &
\end{tabular}

Sources: see footnote 12 .

What were these "fevers"? Were they infectious diseases? Some probably were. In other cases, the symptoms of "fevers" reported by contemporary physicians did not fit

${ }^{10}$ E. M. Sigsworth, 'Gateways to death? Medicine, hospitals, and mortality, 1700-1850', in Peter Mathias (editor), Science and society, 1600-1900, Cambridge University Press, 1972, pp. 97-110; and John Woodward, To do the sick no harm, London, Routledge \& Kegan Paul, 1974, pp. 123-142.

"Charles Creighton, $A$ history of epidemics in Britain, 2 vols., [2nd ed., London, 1894], reprinted London, Frank Cass, 1965, vol. 2, pp. 43-44, 531, 535, 557, and 568; Peter Razzell, The conquest of smallpox, Firle, Sussex, Caliban Books, 1977.

12 Creighton, op. cit., note 11 above, pp. 54, 65, $131,137$. 


\section{Mary Kilbourne Matossian}

into any of the models of common infectious disease (e.g., typhus, typhoid, scarlatina, diphtheria) in the medical textbooks of today. In arguing that the decline in mortality in the second half of the eighteenth century was the result of a decline in infectious disease, McKeown relied not upon eighteenth-century disease descriptions, but upon data for later periods. He argued that since deaths from certain infectious diseases declined in the latter part of the nineteenth century, thereby reducing the mortality rate, then by analogy the same must have been true of the second half of the eighteenth century. ${ }^{13}$

As a matter of fact, descriptions of diseases by late seventeenth- and eighteenthcentury physicians leave much to be desired. Laboratory tests were unknown and autopsies infrequent. Morbidity and mortality statistics were rare. But some clinical descriptions were careful, and the descriptions by different physicians of a disease were often in very close agreement. Investigators in our time may have undervalued these early clinical reports simply because they did not fit the models of common infectious disease.

Perhaps, it will be suggested here, clinical reports of the eighteenth century did not fit infectious disease models because in some cases these models were not appropriate. Two models for fungal poisoning (mycotoxicosis), namely, ergotism and alimentary toxic aleukia (A.T.A.), might have more relevance.

This proposal is new because only since the 1960 s have scholars given much attention to mycotoxicoses caused by microfungi. ${ }^{14}$ Few consider these diseases as important human health hazards today. This being so, no one has inquired as to whether or not they were important health hazards in the past.

Let us look into the descriptions of some of the most prevalent and deadly "fevers" that appeared in Britain during the late seventeenth and early eighteenth centuries. John Huxham, a well-trained physician of Plymouth, in his records from 1724 through 1753, carefully described the "fevers" he was treating. ${ }^{15}$ In his Essay on fevers $(1750)^{16}$ he distinguished "slow nervous fever", which affected the central nervous system without causing massive necrosis and bleeding, from "putrid malignant fever", which did cause massive necrosis and bleeding. Seeking an aetiology for each, he associated "slow nervous fever" with cold, moist weather, and "putrid malignant fever" with warm, moist weather. He founded these distinctions on careful and repeated observations.

\section{SLOW NER VOUS FEVER}

According to Huxham, in its early stages the symptoms of slow nervous fever were: (1) hot and cold sensations; (2) headaches and dizziness; (3) depression; (4) sensitivity to light and noise; (5) nausea and vomiting; (6) rapid pulse, weak, and fluttering; (7) torpor. In later stages the patient might experience: (8) delirium; (9) cold sweats; (10) difficulty in swallowing, gulping, and choking; (11) cold extremities, or nails pale or

${ }^{13}$ McKeown, op. cit., note 1 above, pp. 50-67, 152.

14 G. C. Ainsworth, Introduction to the history of mycology, Cambridge University Press, 1976, p. 186.

is John Huxham, Observations on the air and epidemic diseases, 2 vols., London, 1759-1767.

${ }^{16} \mathrm{John}$ Huxham, An essay on fevers, London, 1750, pp. 74-79. 
livid; (12) tremors and convulsions; (13) diarrhoea; (14) stupor, coma.

In 1742 John Barker, M.D., F.R.C.P., made another careful description of "slow nervous fever", which had been prevalent in the two years just preceding. ${ }^{17} \mathrm{He}$ reported all of the above symptoms, and added the following: in the early stage (15) pain in stomach and limbs; (16) pale urine; (17) fainting fits; (18) deafness; (19) bloody spots just under the skin. In the later stages the patient might experience: (20) insomnia; (21) his eyes might stare or turn out; (22) his limbs might become necrotic, and, in case of survival, (23) persistent mental dysfunction. Barker reported that the disease often affected whole families, or even whole cities, yet he did not think it was contagious. He believed it to be a kind of poisoning: for, he observed, the symptoms resembled those that resulted from taking certain kinds of poison by mouth, e.g., involuntary constriction of blood vessels and "contraction" of the nerve fibres.

As for aetiology, both Huxham and Barker noticed that "slow nervous fever" broke out in the summer and autumn after a severely cold winter. They both suspected bad food as the source of trouble.

"Slow nervous fever" occurred in England in 1700, 1702, 1709-1710, 1726-1729, and especially during 1740-1741. ${ }^{18}$ Elsewhere, in Paris, beginning in the late spring of 1740 and late into 1741 , mortality was high from a disease characterized by convulsions, delirium, headache, nausea, sweating, and pain in the side. ${ }^{19}$ In 1741 in Northern Germany a disease characterized by convulsions in children and young people broke out. ${ }^{20}$ Overall during the period $1700-1750$ so-called "convulsions" were the greatest killer of children in London. ${ }^{21}$

The symptoms of so-called slow nervous fever were also reported in the sixteenth and seventeenth centuries, although more sketchily and not in a medical context. They occurred mainly among children and young people of common birth, who were seldom seem by physicians. The more dramatic symptoms - convulsions, epilepticlike fainting fits, hallucinations, temporary blindness, deafness, and speechlessness, insanity, and gangrene - were reported in pamphlets and court records because these were believed to be symptoms of "bewitchment". The village folk healers who used magic, "witches", were blamed for them. Some detailed descriptions of cases of "bewitchment" are available and they are very similar to those of "slow nervous fever". ${ }^{22}$

17 John Barker, An inquiry into the nature, cause and cure of the present epidemick fever, London, 1742.

"Creighton, op. cit., note 11 above, vol. 1, p. 64; vol. 2, pp. 54-83; David Hamilton, Tractatus duplex de praxeos regulis et de febre miliari, London, 1710; Edward Strother, Practical observations on the epidemical fevers, London, 1729; Richard Manningham, Febricula or little fever, commonly called the nervous or hysteric fever, London, 1746; William Hillary, An account of the principal variations of the weather and the concomitant epidemical diseases from 1726 to 1734 at Rippon, appendix to Practical essay on smallpox, London, 1740; Ebenezer Gilchrist, 'An essay on nervous fevers', Edinb. med. Essays \& Obs., 1737, 4: 347-405; 1744, 5, pt. 2: 505-573; Thomas Short, $A$ general chronological history of the air. weather, seasons, meteors, etc., 2 vols., London, 1749.

19 . Bricourt et al., 'La crise de subsistance des années 1740 dans le ressort du parlement de Paris', Années de démographie historique, 1974, pp. 304-307.

${ }^{20}$ August Hirsch, Handbook of geographical and historical pathology, translated from the German by C. Creighton, 2 vols., London, New Sydenham Society, 1883-1886, vol. 2, p. 207.

${ }^{21}$ Andrew B. Appleby, 'Nutrition and disease: the case of London 1550-1750', J. interdiscipl. Hist., 1975, 6: $1-22$.

${ }^{22}$ Edward Fairfax, Demonologia, London, 1622; and Sadducismus debellatus, London, 1698. C. H. 


\section{Mary Kilbourne Matossian}

What was the diagnosis for these symptoms? While a number of viral infections may produce convulsions and delirium, such infections do not produce necrosis of the limbs. In some cases, at least, Barker's suggestion that "slow nervous fever" was produced by a poison in food appears plausible. We know that in 1740 in England high wheat prices forced common folk to eat "bad bread". ${ }^{23}$ This suggests that the form of poisoning was grain poisoning of some kind.

The toxic agent in question may have been ergot, the sclerotia of a fungus, Claviceps purpurea, which grows on rye. Such infection is most likely to occur after a severe winter. And indeed, the winters (i.e., January-February) of 1709, 1729, 1740, and 1741 were noted for their severity, ${ }^{24}$ and were followed by outbreaks of "slow nervous fever".

Ergot is a purple-brown structure; its complex natural chemical composition may vary and hence the symptoms it produces may vary accordingly. It consists of three kinds of alkaloids: ergotamine, dihydroergotamine + dihydroergotoxine, and ergonovine. When dry and present in well-preserved rye flour, ergot is not unpleasant to smell or taste; it is, therefore, an insidious toxin.

According to Bove, ergotism affects every part of the human body. A great variety of symptoms is typical of an ergotism epidemic, with considerable variation from one patient to another. ${ }^{25}$ There are two kinds of ergotism, gangrenous and convulsive, but the early symptoms of both are the same.

Ergotism is more likely to occur in children than adults. Its symptoms usually appear first either in late spring, when the winter rye crop is harvested, or in late summer, when the summer rye crop is harvested. In time of food shortage, poor farmers are most likely to suffer from ergotism, for, having exhausted their food supplies from the previous year, they are apt to consume the new rye crop without carefully sifting and washing the grain. How long the epidemic lasts depends upon the level of ergot at harvest and also upon the conditions of storage. If stored in a cool, dry place at $21-27^{\circ} \mathrm{C}$, ergot may deteriorate only negligibly for seventeen months.

If the descriptions of "bewitchment" and "slow nervous fever" are matched with the model for ergotism, no significant discrepancies are found. Convulsions and psychotropic symptoms are combined with symptoms of vasoconstriction, such as a weak, rapid pulse, lameness, and gangrene. Children and teenagers are the most common victims.

Since ergot does not commonly occur on cultivated grain other than rye, the incidence of ergotism is linked with the incidence of rye consumption; any decline in the latter should cause a decline in the former. By the early 1620 s in south-eastern England the common folk had shifted from dependence on rye to dependence on

\footnotetext{
L'Estrange Ewen, Witchcraft and demonianism, London, Heath Cranton, 1933, pp. 191-192; Thomas Wright, Narratives of sorcery and witchcraft, (reprint of 1851 ed.), Detroit, Mich., Gale, 1971, pp. $254-276$. ${ }^{23}$ Creighton, op. cit., note 11 above, vol. 2, p. 79.

24 Manley, op. cit., note 7 above, pp. 389-405.

${ }^{25}$ F. J. Bove, The story of ergot, Basle, Karger, 1970, pp. 9, 16-17, 31, 65, 178, 215; G. C. Merhoff, 'Ergot intoxication: historical review and description of unusual clinical manifestations', Ann. Surg., 1974, 180: 773-779; George Barger, Ergot and ergotism, London, Gurney \& Jackson, 1931, pp. 21-39, 98-99.
} 
wheat as a staple grain. ${ }^{26}$ Here the incidence of witch persecution declined in the 1620 s. $^{27}$ But rye continued to be cultivated farther north during the seventeenth and early eighteenth centuries, and as late as 1697 six alleged witches were executed in Scotland for "bewitching" an eleven-year-old girl with classic symptoms of ergotism. The same symptoms, labelled "nervous fever", persisted in the accounts of physicians through 1741; after this, rye ceased to be an important part of the English diet. (See Table 2.)

TABLE 2 EPIDEMICS OF SLOW NERVOUS FEVER IN ENGLAND, 1667-1741

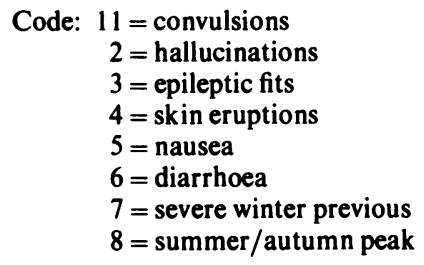

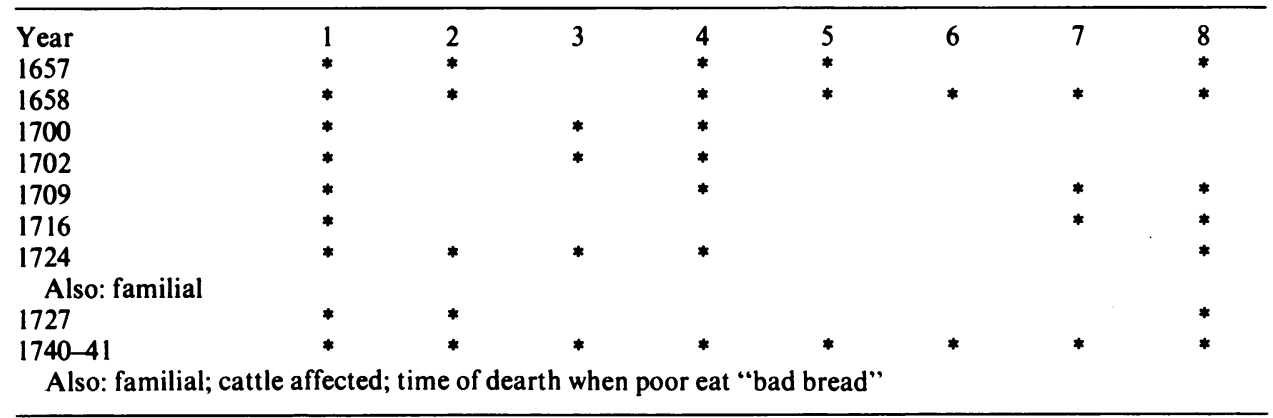

Sources: Creighton, op. cit., footnote 1, vols. 1-2 passim; Short, op. cit., footnote 18, vols. 1-2 passim; Huxham, op. cit., footnote 15.

\section{PUTRID MALIGNANT FEVER}

Another great child killer in the first half of the eighteenth century was "putrid malignant fever". Huxham ${ }^{28}$ gives its symptoms as follows: in the early phase, (1) pulse tense, hard, quick, small; (2) headache, dizziness; (3) nausea and vomiting; (4) depression and weakness; (5) laboured breathing; (6) foul breath. In the middle phase came: (7) vomiting of black matter; (8) the urine got dark, had a foul smell; (9) bloody or black stools; (10) bloody spots on the skin, sometimes bleeding; sometimes white miliary pustules or a red rash; (11) cold sweats; (12) difficulty in swallowing, pain and ulceration of fauces, oesophagus, etc. In the terminal phase came: (13) bloody diarrhoea, ulceration of the intestines; (14) vibices (large black and blue marks like bruises); (15) the extremities became cold and livid.

${ }^{26}$ Eric Kerridge, The farmers of old England, London, Allen \& Unwin, 1973, p. 163.

${ }^{27}$ Alan Macfarlane, Witchcraft in Tudor and Stuart England. A regional and comparative study, London, Routledge \& Kegan Paul, 1970.

${ }^{28}$ Huxham, op. cit., note 16 above, pp. 92-96. 


\section{Mary Kilbourne Matossian}

In this disease the characteristic quartet of severe symptoms was: (1) a tendency to bleed; (2) skin eruptions; (3) sore and ulcerated throat; and (4) putrid smell. One other symptom, not mentioned by Huxham but by William Douglass in New England, was that in the initial stage patients suffered from a "pepperish" sensation in the mouth. This relatively minor symptom may be important.

As for the epidemiology of "putrid malignant fever", Huxham ${ }^{29}$ observed that it occurred in late spring and early summer after a warm, moist winter. Johnstone $e^{30}$ agreed; in addition, he associated the incidence of the disease with low, marshy land; food scarcity, especially of grain, since questionable food was liable to be eaten at such times; and long sea voyages in wet weather. He observed that many children in a family were likely to be affected and sometimes adults as well. Morbidity was highest among those aged ten to fifty years; mortality was highest among children and the aged.

So far, none of the diagnoses suggested for "putrid malignant fever" can be correct. Typhus fever and scarlatina can be ruled out because an ulcerous sore throat and a tendency to bleed are not characteristic of these diseases. Diphtheria can be ruled out because in that disease throat ulceration is unusual; skin lesions occur, but only in tropical areas when the skin is broken by a wound or burn; and a tendency to bleed is not typical. Today the symptoms of aplastic anaemia and agrunulocytosis are similar to those of "putrid malignant fever". The incidence of these diseases in sporadic, and adults are more often affected than children. In many cases of these diseases the aetiology is unknown. ${ }^{31}$ Could it be that a fungal agent may be involved?

A more plausible diagnosis of "putrid malignant fever", is an epidemic, noncontagious, non-infectious disease known as alimentary toxic aleukia (A.T.A.), identified in the Soviet Union between 1942 and 1947. It is caused by the fungus Fusarium tricinctum. An infection by this fungus may cause black spotting of the grain, although not necessarily. A strain of Fusarium tricinctum has been found to produce a potent trichothecene toxin, T-2 toxin, capable of causing the symptoms of A.T.A. in laboratory animals. ${ }^{32}$ This toxin affects the bone marrow, causing a lengthening of clotting and pro-thrombin time, and an increase in vascular permeability.

The course of A.T.A. ${ }^{33}$ has three stages. In the first stage, usually lasting three to five days, the individual experiences a burning or "peppery" sensation in the mouth

\footnotetext{
${ }^{29} \mathrm{Huxham}$, op. cit., note 15 above, vol. 1, p. 140; John Huxham, Dissertation on the malignant ulcerous sore throat, London, 1757, p. 3.

${ }^{30} \mathrm{James}$ Johnstone, $A$ historical dissertation concerning the malignant epidemic fever of 1756 , London, 1758, pp. 53, 64 .

${ }^{31}$ M. M. Wintrobe et al. (editors), Harrison's principles of internal medicine, 7th ed., New York, McGraw-Hill, 1974.

${ }^{32}$ E. B. Smalley, et al., 'Mycotoxicoses associated with moldy corn', Toxic Microorganisms: Mycotoxins, Botulism, 1970, 163-175; N. R. Kosuri, E. B. Smalley, and R. E. Nichols, 'Toxicologic studies of Fusarium tricinctum (Corda) Snyder et Hansen from moldy corn', Amer. J. vet. Res., 1971, 32: 1843-1850; A. N. Leonov, 'Current view of the chemical nature of factors responsible for alimentary toxic aleukia', Mycotoxins in Human and Animal Health, 1977, 323-328; B. Yagen, A. Z. Joffe, P. Horn, et al., 'Toxins from a strain involved in ATA', ibid., 329-336.

${ }^{33} \mathrm{C}$. F. Mayer, 'Endemic panmyelotoxicosis in the Russian grain belt', Military Surgeon, 1953, 113: 173-189, 295-315; J. Forgacs and W. T. Carll, 'Mycotoxicoses', Advances in Veterinary Science, 1962, 7: 273-382.
} 
shortly after eating food prepared from grain containing the toxin. This grain may be wheat, rye, oats, buckwheat, barley, corn, or millet. For two or three days the victim may experience nausea, vomiting, and diarrhoea, and then for two to eight weeks be symptom-free except for an unpleasant taste in the mouth. Thus the connexion between the first stage and the quiescent second stage, with the third, acute, stage is likely to be missed.

In the third stage A.T.A. masquerades as an acute febrile disease: the temperature is $102-104^{\circ} \mathrm{F}$. The four characteristic symptoms of severe "putrid malignant fever" are present: a tendency to bleed, skin eruptions, sore and ulcerated throat, and putrid smell. In both diseases, the patient may die of strangulation due to swelling of throat and neck tissues, or of pulmonary complications. Central nervous system symptoms may be present.

A.T.A. is familial disease, affecting usually several members of the same family. Children under the age of five and adults over fifty years who contract it are most likely to die, and 40-50 per cent of children under the age of ten who contract it will die. This high mortality among children and the familial character also fits the incidence of "putrid malignant fever".

In A.T.A., as in "putrid malignant fever", morbidity is highest among persons aged eight (10) to fifty (40) years, varying somewhat according to specific outbreaks. It is most likely to appear in low, marshy lands, in spring following a mild winter. It is likely to appear in time of food scarcity, as was the case in Russia during World War II, and in England in 1756, when the most widespread epidemic of "putrid malignant fever" occurred. In the Soviet Union T-2 toxin was probably formed in grain left standing in the fields during the winter and harvested in April. But T-2 toxin may also form in stored grain containing more than 16 per cent moisture, especially in an illventilated granary. ${ }^{34}$

And so it appears that a disease with symptoms and epidemiology remarkably like those of A.T.A. was present in England in the eighteenth century. Was it also present earlier? Disease descriptions for the sixteenth and seventeenth centuries are sketchy. However, some evidence does exist. Thomas Short compiled data about epidemics both in England and Europe, attending climatic conditions, and the character of the harvest, for almost every year during these centuries. ${ }^{35}$ Since he approached disease empirically, without any grand theory, and he believed in the importance of environmental influences, he is a valuable witness today.

The data in Table 3 is not sufficient to support a diagnosis of alimentary toxic aleukia prior to 1661-1662; it is nevertheless presented because it seems suggestive.

The epidemic of $1555-1558$ was highly mortal. ${ }^{36}$ Its symptoms, as reported by Short, resemble those of "putrid malignant fever", except that throat ulceration is not mentioned in England; it is mentioned in relation to epidemics in Spain and the Netherlands in the same period, however. The season of onset and the age and familial

${ }^{34}$ Smalley et al., op. cit., note 32 above.

${ }^{35}$ Short, op. cit., note 18 above.

36 David Palliser, 'Dearth and disease in Staffordshire, 1540-1670', in Charles W. Chalk lin and Michael A. Havinden (editors), Rural change and urban growth, London, Longmans, 1974, pp. 57-58. 


\section{Mary Kilbourne Matossian}

relationships of the victims of this epidemic have not been studied. However, Short mentioned that in 1557 "all grain was choaked and blasted" on account of the excessive raininess. ${ }^{37}$

TABLE 3 EPIDEMICS OF PUTRID MALIGNANT FEVER IN ENGLAND, 1513-1756

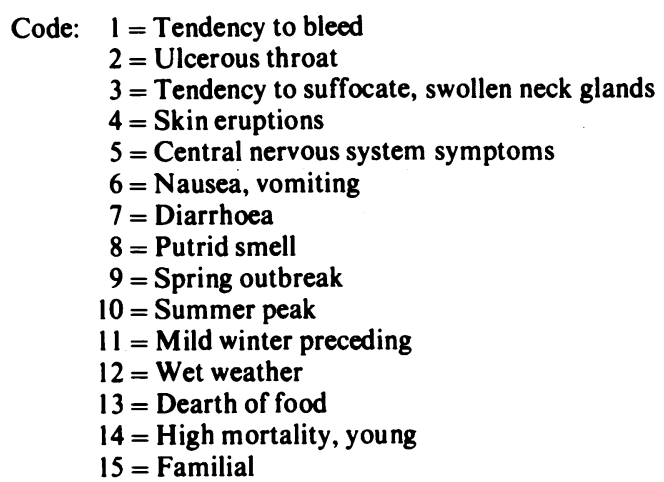

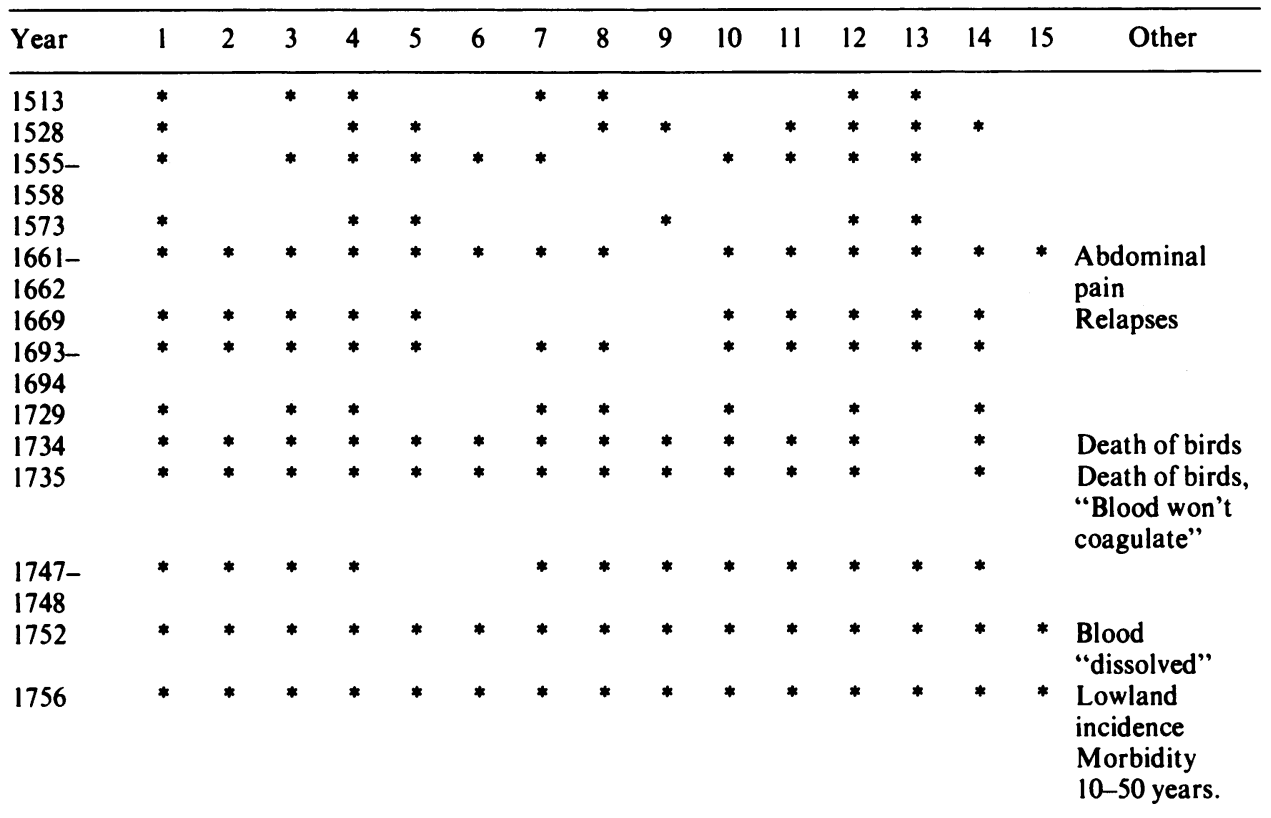

Sources: Short, op. cit., footnote 18; Fothergill, op. cit., footnote 38; Huxham, op. cit., footnote 29; Huxham, op. cit., footnote 15, vol. 1; James Johnstone, $A$ treatise on the malignant angina, or, putrid and ulcerous sore throat, Worcester, 1758; H. H. Lamb, Climate. Present, past, and future, 2 vols., London, Methuen, 1977, vol. 2.

${ }^{37}$ Short, op. cit., note 18 above, vol. 1, p. 22. 


\section{Mold poisoning: an unrecognized English health problem, 1550-1800}

The epidemic of 1661-1662 was described by Dr. Thomas Willis, an acute professional observer. He did not mention the season of onset of the epidemic, but otherwise his description fits the A.T.A. model quite well. He reported that mortality in this epidemic (as in A.T.A.) was high not only among the young but among the elderly.

In the eighteenth century the years in which well-described similar epidemics occurred were 1734-1735, 1742-1748, 1752, and 1756.

\section{THE DECLINE OF “FEVERS” AFTER 1750}

Epidemics of "slow nervous fever" ceased in England after 1741. They were rare in Ireland during the eighteenth century. Epidemics of "putrid malignant fever" were less often observed in the second half of the eighteenth century. They were absent between 1760-1777 and 1779-1785 in England, and between 1760-1771 and 1772-1797 in Ireland..$^{38}$ Mortality from this fever may have fallen.

Since ergot usually infects rye, any change in the amount of rye consumption may influence the incidence of ergotism. And such a change did occur in England. Around 1700 much rye was grown in Lancashire, Yorkshire, Staffordshire, Herefordshire, Worcestershire, Suffolk, and Norfolk. ${ }^{39}$ Wheat prices being low, a gradual shift from rye to wheat consumption occurred during the next fifty years. ${ }^{40}$ Around 1750 wheat prices fell to the point that wheat was as cheap as rye. By 1770 a great majority of the people were entirely dependent on wheat for bread. When wheat prices went up (1709, $1740,1756-57,1766-67,1773,1782$, and 1795) the people chose to riot rather than switch to dark bread made of rye or mixed grains. They claimed that the latter made them feel hot, weak, and nauseated. ${ }^{41}$ This change in diet alone would account for the virtual disappearance of "slow nervous fever" in England.

As for alimentary toxic aleukia, T-2 toxin may have formed on three common eighteenth-century British crops: wheat, oats, and barley. But after the crop failure of 1756 the cultivation of the potato increased in Great Britain. The process was gradual until a crop failure in 1795 , after which the consumption of potatoes rapidly increased in England. By 1805 the potato had "taken command" and "putrid malignant fever" became less common. ${ }^{42}$

The case of Ireland is useful for comparison. Throughout the eighteenth century the Irish were heavily dependent on the potato, although they consumed some bread as well. The population of Ireland grew much more rapidly than that of Great Britain.

\footnotetext{
${ }^{38}$ Hillary, op. cit., note 18 above, pp. 3, 20, 123-126; Huxham op. cit., note 29 above, pp. 7-31; Huxham, op. cit., note 15 above, passim; Edinb. med. Essays \& Obs., 1735, 3: 26; John Fothergill, An account of the sore throat attended with ulcers, London, 1758; John Rutty, Chronological history of the weather and seasons and prevailing diseases in Dublin during forty years, London, 1770; William Withering, Account of the scarlet fever and sore throat, London, 1779; Creighton, op. cit., note 11 above, vol. 2, pp. 683-684, $691-718$.

${ }^{39}$ B. H. Slicher van Bath, The agrarian history of Western Europe, A.D. 500-1850, translated by Olive Ordish, London, Edward Arnold, 1963, pp. 263-267.

${ }^{20}$ Sir Jack Cecil Drummond and Lady Drummond, The Englishman's food. A history of five centuries of English diet, London, Cape, 1939, p. 178.

"E. P. Thompson, 'The moral economy of the crowd in eighteenth-century England', Past and Present, 1971, 50: 79-82.

${ }^{42}$ Salaman, op. cit., note 8 above, pp. 480-496.
} 


\section{Mary Kilbourne Matossian}

The Irish numbered about 1,034,000 in 1695 and 4,206,612 in 1791, an increase of about 400 per cent..$^{43}$ The English, who were slow to adopt the potato, grew only 157 per cent during the eighteenth century, ${ }^{44}$ while the Scots increased about 148 per cent. ${ }^{45}$

It has been thought that the potato, since it yields two to three times as many calories per acre as rye, for example, caused the increase in the Irish population simply by providing it with more calories. Yet the English population had ample calories, and a more varied diet, than the Irish between 1700-1750, and it did not increase at the same rate. One reason was the earlier age of marriage of the Irish. But another may have been that the potato on which they depended did not harbour the toxins of Claviceps purpurea and Fusarium tricinctum. To be sure, the potato may be infected by other fungi, but such infections are obvious, not insidious.

\section{SUMMARY}

The evidence presented here supports the hypothesis that two forms of fungal poisoning, ergotism (caused by the infection of rye by Claviceps purpurea) and alimentary toxic aleukia (caused by the infection of a variety of cereal grains by Fusarium tricinctum), made important contributions to child mortality in England between 1700 and 1750 and probably earlier as well. There is evidence that suggests that these diseases may have been prevalent in England in the late seventeenth and early eighteenth centuries. The decline in child mortality after 1750 may be partly attributed to a decline in the incidence of these diseases. Crop substitutions and climatic changes may have been responsible for these developments.

\footnotetext{
${ }^{43} \mathrm{~K}$. H. Connell, The population of Ireland, 1750-1845, London and Westport, Conn., Greenwood Press, 1975 , p. 4.

${ }^{4}$ Chambers, op. cit., note 7 above, p. 108.

"s Michael Flinn (editor), Scottish population history from the seventeenth century to the 1930s, Cambridge University Press, 1977, pp. 241, 302.
} 